\title{
Are orchid bees at risk? First comparative survey suggests declining populations of forest-dependent species
}

\author{
Nemésio, A.* \\ Instituto de Biologia, Universidade Federal de Uberlândia - UFU, Rua Ceará, s/n, \\ Campus Umuarama, CEP 38400-902, Uberlândia, MG, Brazil \\ *e-mail: andre.nemesio@gmail.com
}

Received March 1, 2012 - Accepted May 18, 2012 - Distributed May 31, 2013

(With 2 figures)

\begin{abstract}
The two largest Atlantic Forest remnants in the state of Espírito Santo, eastern Brazil, namely 'Reserva Biológica de Sooretama' (REBIO Sooretama) and 'Reserva Natural Vale' (RNV), were surveyed for their orchid-bee faunas. Seventeen scent baits were used to attract orchid-bee males. Three-thousand, two hundred and twenty-five males belonging to 24 species were actively collected with insect nets during 100 hours in March, April and December, 2009. In comparison with a previous study in the same area twelve years before, it is evident that the abundance of all forest-dependent orchid bees analysed declined around $50 \%$, and it was statistically significant $(\mathrm{P}=0.022)$ for Euglossa marianae Nemésio, 2011, the most sensitive to anthropogenic disturbances of all Atlantic Forest orchid bees. On the other hand, the abundance of populations of species tolerant to open or disturbed areas rose. Possible explanations are discussed.
\end{abstract}

Keywords: Apidae, Atlantic Forest, conservation, Euglossina, euglossine bees, Hymenoptera.

\section{As abelhas-das-orquídeas estão ameaçadas? Primeiro levantamento comparativo sugere populações em declínio das espécies dependentes de ambientes florestais}

\begin{abstract}
Resumo
Os dois maiores remanescentes de Mata Atlântica no Estado do Espírito Santo, leste do Brasil, precisamente a Reserva Biológica de Sooretama (REBIO Sooretama) e a Reserva Natural Vale (RNV), tiveram suas faunas de abelhas-dasorquídeas amostradas. Dezessete iscas atrativas a machos de abelhas-das-orquídeas foram utilizadas. Um número de 3.225 machos, pertencentes a 24 espécies, foi ativamente coletado, com o auxílio de redes entomológicas, durante 100 horas, em março, abril e dezembro de 2009. Uma comparação com um estudo prévio realizado na mesma área 12 anos antes revelou que a abundância relativa das populações de abelhas dependentes de ambientes florestais declinou em torno de 50\%. Tal declínio foi estatisticamente significante $(\mathrm{P}=0,022)$ para pelo menos uma espécie, Euglossa marianae Nemésio, 2011, a espécie mais sensível a perturbações antrópicas. Por outro lado, a abundância relativa das populações de espécies tolerantes às áreas abertas ou perturbadas aumentou. Possíveis explicações são discutidas.
\end{abstract}

Palavras-chave: Apidae, Mata Atlântica, conservação, Euglossina, abelhas euglossinas, Hymenoptera.

\section{Introduction}

Studies on the effects of habitat fragmentation on populations of orchid bees (Hymenoptera: Apidae: Euglossina) in the Amazon have shown that some species are much less tolerant to anthropogenic disturbances than others (e.g., Powell and Powell, 1987; Morato et al., 1992; Morato, 1994). If the same is true for orchid-bee species in the Atlantic Forest domain, a highly fragmented biome, the obvious implications would be that a suitable environment could become very limited for some species. Indeed, recent studies (Tonhasca Junior et al., 2002a; Nemésio and Silveira, 2006a; Giangarelli et al., 2009) have suggested that some Atlantic Forest species may be intolerant to disturbed areas and, thus, restricted to the few larger areas that still hold suitable habitats. Nemésio (2009) carried out the first attempt to evaluate the conservation status of each orchid-bee species occurring in the Atlantic Forest under IUCN criteria, and suggested that a few species should be included in some of the risk categories. More recently, an apparent local extinction was reported (Nemésio, 2011b) and additional surveys extended our knowledge on the actual geographic distributions of many of the rarest species (Nemésio 2010b, 2011a, e, Nemésio et al., 2012).

Despite being sampled at least since the end of the $19^{\text {th }}$ century (Mocsáry, 1896, 1897; Friese, 1899), the orchid-bee fauna from the state of Espírito Santo remains virtually unknown and only accessible to those who study museum specimens. Only recently data from some forest preserves located in the northernmost portion of Espírito Santo were made available in the literature (BonillaGómez, 1999; Nemésio, 2011b), although the study by 
Bonilla-Gómez (1999) has never been formally published. This situation becomes even more evident when one considers that the orchid-bee faunas of the neighbouring states of Bahia (Raw, 1989; Neves and Viana, 1997, 1999, 2003; Nemésio, 2011a, b, c, 2012), Minas Gerais (Peruquetti et al., 1999; Nemésio and Silveira, 2004, 2006a, b, 2007, 2010; Nemésio, 2003, 2008a, b; Nemésio and Faria Junior, 2004; Alvarenga et al., 2007) and Rio de Janeiro (Tonhasca Junior et al., 2002a, b, 2003; Aguiar and Gaglianone, 2008, 2011; Ramalho et al., 2009) have at least a part of their area well sampled and known for orchid bees.

Nevertheless, it is not common to find data in the literature involving surveys in the same area at different times. Thus, it is impossible to evaluate changes in community composition over the years and assess if any species population are declining or not, particularly of those more sensitive species. Change in population size is one important criterion to estimate the possible fate of a species (locally or globally) according to IUCN risk categories (IUCN, 2001).

The state of Espírito Santo is an ideal and obvious candidate to try a "second survey" at the same site. Most of the original forest cover in Espírito Santo was wiped out and deforestation was particularly severe in the northernmost portion of the state, where only scattered fragments remain (Fundação SOS Mata Atlântica, 1993; Ribeiro et al., 2009), the largest of them, 'Reserva Biológica de Sooretama', not exceeding 24,000 ha (Ribeiro et al., 2009). This region, however, together with the southernmost portion of the state of Bahia, holds one of the most exuberant portions of the Atlantic Forest. More importantly, the oldest full survey in a large forest remnant was carried out at 'Reserva Natural Vale' (22,000 ha) in 1996 and 1997 (Bonilla-Gómez, 1999). Together with the adjacent 'Reserva Biológica de Sooretama', these two areas represent around $10 \%$ of all remaining vegetation cover for Espírito Santo (Fundação SOS Mata Atlântica, 1993).

The main goals of this study were, thus: (i) re-sample 'Reserva Natural Vale' in order to estimate possible changes in its orchid-bee community, especially populations of the most sensitive species; (ii) sample for the first time the neighbor 'Reserva Biológica de Sooretama', in order to expand distributional and taxonomic knowledge on the orchid bees of the Brazilian Atlantic Forest, with special emphasis to the region of northern Espírito Santo, by providing relevant data on the orchid-bee species found in a poorly known area of one of the most threatened biomes in the world.

\section{Material and Methods}

\subsection{Study sites}

This study was conducted at 'Reserva Biológica de Sooretama' (REBIO Sooretama), a 24,000-ha preserve belonging to the Brazilian government, situated in the municipality of Sooretama, and at 'Reserva Natural Vale' (RNV), a 22,000-ha particular preserve situated in the municipality of Linhares, in the state of Espírito Santo, southeastern Brazil (Figure 1), in March, April and
December, 2009, during the summer in Brazil, when orchid bees are most actively foraging (e.g., Martins and Souza, 2005). Both preserves are connected through a narrow patch (in the easternmost end of 'REBIO Sooretama' and the northwesternmost section of RNV - see Figure 1). Thus, both preserves may be treated as a whole continuous 46,000-ha area, since many animals can use both areas freely (a federal road lies between both preserves, which limits the faunal interchange). Vegetation in this area is essentially dense Atlantic Rain Forest according to the vegetation map of Brazil (IBGE, 1993), or as lowland rain forest (Oliveira-Filho and Fontes, 2000), but 'REBIO Sooretama' is more compact, with a lower perimeter than RNV, which is roughly divided into three large blocks of vegetation with a very large perimeter (i.e., it suffers more pronounced effects around the border than 'REBIO Sooretama') (see Figure 1). 'Reserva Natural Vale' is also closer to the coast than 'REBIO Sooretama' and there are more patches of vegetation situated on sandy soil, the socalled 'mussunungas', which consists in sparser and lower vegetation. The climate is wet tropical (Aw) with a rainy season in summer and a dry season in winter. Precipitation in the area is $c a .1,200 \mathrm{~mm} /$ year, with a strong variability from year to year (Srbek-Araújo et al., 2009).

\subsection{Sampling}

Due to logistics, only one site was sampled in 'REBIO Sooretama'. Four sites were sampled in RNV to better assess the different phytophysiognomies found at this preserve. Twenty hours of active sampling with insect nets were performed in each of the selected sites, totalling 100 hours (20 hours in 'REBIO Sooretama' and 80 hours in RNV), following the methodology proposed by Nemésio (2010a, b, 2011a, b). The four sites at RNV are here treated as RNV-1 to RNV-4. The exact locations of all sampling sites are as follows: 'REBIO Sooretama' site $\left(19^{\circ} 02^{\prime} 47^{\prime}\right.$ ' S and $40^{\circ} 08^{\prime} 55^{\prime}$ ' W, ca. $60 \mathrm{~m}$ above sea level) was sampled on the $12^{\text {th }}$ (from 07:00h to 15:00h), $13^{\text {th }}$, (from 07:00h to $14: 00 \mathrm{~h}$ ), and $14^{\text {th }}$ (from 08:00h to 13:00h) of December, 2009; RNV-1 (190 $08^{\prime} 52^{\prime \prime}$ S-40 02 ' 57 ' W, ca. $50 \mathrm{~m}$ above sea level) was sampled on the $31^{\text {st }}$ of March (from 08:00h to 16:00h), $2^{\text {nd }}$ (from 09:00h to $14: 00 \mathrm{~h}$ ) and $4^{\text {th }}$ (from 09:00h to 16:00h) of April, 2009; RNV-2 (19 $08^{\prime} 35^{\prime}$ ' S-39 $55^{\circ}$ ' 15 ” W, ca. $50 \mathrm{~m}$ above sea level) was sampled on the $1^{\text {st }}$ (from $08: 00 \mathrm{~h}$ to $\left.16: 00 \mathrm{~h}\right), 3^{\text {rd }}$ (from 09:00h to 14:00h), and $7^{\text {th }}$ (from 09:00h to 14:00h) of April, 2009; RNV-3 (19 10' 52" S-39 56' 32" W, ca. $50 \mathrm{~m}$ above sea level) was sampled on the $5^{\text {th }}$ (from $09: 00 \mathrm{~h}$ to $15: 00 \mathrm{~h}), 7^{\text {th }}$ (from $08: 00 \mathrm{~h}$ to $14: 00 \mathrm{~h}$ ), and $8^{\text {th }}$ (from 08:00h to 16:00h) of April, 2009; RNV-4 (19 09' 23" S-40 02 ' 32" W, ca. $45 \mathrm{~m}$ above sea level) was sampled on the $10^{\text {th }}$ (from $07: 00 \mathrm{~h}$ to $14: 00 \mathrm{~h}$ ), $15^{\text {th }}$ (from $07: 00 \mathrm{~h}$ to $15: 00 \mathrm{~h}$ ), and $16^{\text {th }}$ (from $07: 00 \mathrm{~h}$ to $12: 00 \mathrm{~h}$ ) of December, 2009. Sites RNV-2 and RNV-3 were situated closer to the coast, in areas close to 'mussunungas' (the Atlantic Forest grown in sandy soils) - exactly the same sites; 'Paraju' and 'Farinha Seca', which were sampled by Bonilla-Gómez (1999). Sites RNV-1 and RNV-4 were situated in areas far from 'mussunungas' - close to the site 'Peroba Osso' in Bonilla-Gómez (1999), areas of dense pristine forest. At each site, 17 scent baits were placed 

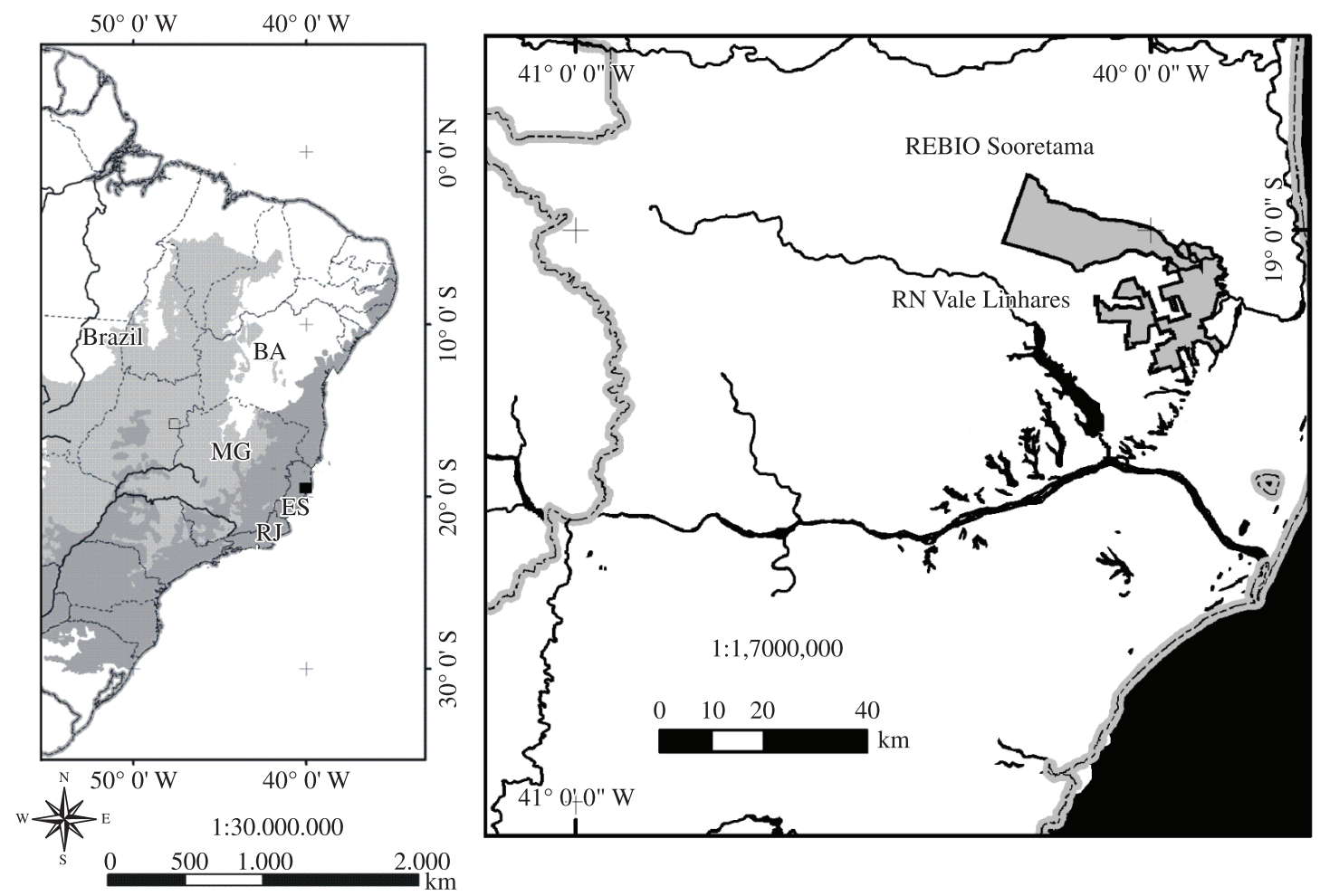

Figure 1. Map showing the location of both 'REBIO Sooretama' and 'Reserva Natural Vale' in Espírito Santo, eastern Brazil. $\mathrm{BA}=$ Bahia; $\mathrm{ES}=$ Espírito Santo; $\mathrm{MG}=$ Minas Gerais; RJ = Rio de Janeiro.

ca. 2.0 meters apart from each other at about $1.5 \mathrm{~m}$ above the ground. These baits were made of cotton wadding soaked with one of the following substances, known or believed to be attractive to orchid bees: benzyl acetate, benzyl alcohol, $r$-carvone, 1,8-cineole, $p$-cresol acetate, dimethoxybenzene, eugenol, $\beta$-ionone, methyl benzoate, methyl trans-cinnamate, heneicosane, methyl salicylate, skatole, tricosane, $p$-tolyl acetate, vanillin, and a mixture (1:1) of methyl trans-cinnamate and $p$-tolyl acetate. Baits with cineole, the most volatile compound, were recharged every hour. Bees arriving on the baits during the sampling period were collected with insect nets and killed with ethyl acetate. They were labelled as belonging to the project "Euglossina da Hileia Baiana" and were deposited at the Entomological Collection of 'Universidade Federal de Minas Gerais' (UFMG), where they were numbered from $17087-48012$ to $17334-49433$ (specimens collected in December, 2009) and from 21643-62650 to 21980-64711 (specimens collected in March and April, 2009).

\subsection{Data analysis}

Diversity was estimated through Shannon-Wiener diversity index $\left(\mathrm{H}^{\prime}\right)$, as $\mathrm{H}^{\prime}=-\Sigma \mathrm{p}_{\mathrm{i}} \ln \left(\mathrm{p}_{\mathrm{i}}\right)$, where $\mathrm{p}_{\mathrm{i}}$ is the proportion of the total number of species made up of the ith species (Pielou, 1975). Evenness (E) was estimated through the formula $E=H^{\prime} / \ln (S)$, where $S$ is the species richness. The similarity in faunistic composition among all sites was estimated by the percent similarity index of Renkonen, recommended by Wolda (1981) for small samples. Based on those similarities, the areas were grouped using UPGMA (Sneath and Sokal, 1973).

\subsection{Comparison to previous study}

Bonilla-Gómez (1999) sampled RNV for one year (September, 1996 to August, 1997) with monthly samplings at each site from 08:00h to 13:00h. She selected three areas at RNV and three sampling sites in each area. Thus, nine sites, five hours for each site, monthly, during a whole year were sampled. It totals to 60 hours per site during one year, or 540 hours of sampling during her study. Bonilla-Gómez (1999) sampled (she did not collect all specimens) 16,177 specimens, or 30 specimens/hour. In the present study, one to two sampling sites in each one of Bonilla-Gómez's (1999) areas were selected. RNV-1 and RNV-4 corresponds to her 'Peroba Osso' site; RNV-2 corresponds to her 'Paraju' site, and RNV-3 corresponds to her 'Farinha Seca' site. Bonilla-Gómez (1999) observed two peaks of abundance and richness at RNV, one at the end of the rainy season (March-April) and the second one at the beginning of the rainy season (November-December), which are the exact seasons chosen in this work to sample the area, to make both data sets comparable. BonillaGómez (1999) used five scent baits (cineole, eugenol, methyl-salycilate, skatole and vanillin), all of them are used in the present study. However, twelve more scents were used in this study, see above. In order to compare possible changes in the community composition, all species with well-defined habitat preferences were selected (those tolerant to open / disturbed habitats and those dependent on forest interior) based on previous studies (e.g. Morato, 
1998; Tonhasca Junior et al., 2002a; Nemésio and Silveira, 2006a; Nemésio 2010b, 2011a, b). Euglossa mixta Friese, 1899 and Euglossa retroviridis Dressler, 1982 specimens in Bonilla-Gómez's (1999) study were grouped together as Euglossa mixta, since this distinction was previously considered as a misidentification (see Nemésio, 2009). The bees listed as Euglossa chalybeata Friese, 1925, Euglossa cordata (Linnaeus, 1758) by Bonilla-Gómez (1999) are here treated as Eg. marianae Nemésio, 2011b, Eg. roubiki Nemésio, 2009 and Eg. carolina Nemésio, 2009, respectively. Two data sets were used: (i) the relative abundance of each species (when compared to the overall community), and (ii) the absolute abundance of each species (number of specimens/sampling effort in hours) in each sampling site. The hypothesis that the absolute abundance of these species changed through time was evaluated using $t$-tests. Data were square-root transformed prior to the analyses in order to meet the requirements of data normality.

\subsection{Taxonomy}

Taxonomy follows Nemésio and Rasmussen (2011) with the additions provided by Hinojosa-Díaz et al. (2012), Nemésio (2012) and Nemésio and Engel (2012).

\section{Results}

Three thousand, two hundred and twenty-five orchid-bee males belonging to 24 species in four genera were collected in 'REBIO Sooretama' and RNV (Table 1). Euglossa carolina was the most common species in all sampling sites in both preserves, but its relative abundance was lower in 'REBIO Sooretama' ( $28 \%$ of the total community) than in RNV (it reached $70 \%$ and $67 \%$ of the total community at RNV-2 and RNV-3, respectively) (Table 1). Eulaema nigrita Lepeletier, 1841, Eg. marianae, Eg. imperialis Cockerell, 1922, Eg. roubiki, Eg. mixta and Eg. ignita Smith, 1874 were the only species, besides Eg. carolina, with more than one hundred (3\% of the total bees) sampled as males. Only one species, Eg. liopoda Dressler, 1982, was represented by a singleton. The site at 'REBIO Sooretama' presented the highest diversity $\left(H^{\prime}=2.36\right)$ and evenness $(E=0.79)$, whereas at RNV diversity ranged from $\mathrm{H}^{\prime}=1.33(\mathrm{RNV}-2)$ to $\mathrm{H}^{\prime}=2.15$ (RNV-4), and evenness ranged from $\mathrm{E}=0.44$ $(\mathrm{RNV}-2)$ to $\mathrm{E}=0.69$ (RNV-4) (see Table 1). Abundance was the highest at RNV-2 (more than 54 bees collected per hour) and ranged from 17 bees/hour to 31 bees/hour in the remaining sites (Table 1). The ordination of the

Table 1. Diversity, species richness, evenness and number of specimens of each orchid-bee species collected at 'REBIO Sooretama' and 'Reserva Natural Vale', state of Espírito Santo, southeastern Brazil, after 20 hours of sampling at each site. Soo $=$ 'REBIO Sooretama'; RV1-RV4 $=$ sites 1 to 4 at 'Reserva Natural Vale'.

\begin{tabular}{|c|c|c|c|c|c|c|}
\hline Species & Soo & RV1 & RV2 & RV3 & RV4 & Total \\
\hline Eufriesea atlantica Nemésio, 2008 & 03 & 00 & 00 & 00 & 01 & 04 \\
\hline Eufriesea surinamensis (Linnaeus, 1758) & 00 & 00 & 00 & 00 & 11 & 11 \\
\hline Euglossa augaspula Hinojosa-Díaz, Nemésio \& Engel, 2012 & 15 & 16 & 16 & 13 & 31 & 91 \\
\hline Euglossa avicula Dressler, 1982 & 01 & 01 & 05 & 02 & 04 & 13 \\
\hline Euglossa carolina Nemésio, 2009 & 176 & 165 & 757 & 394 & 240 & 1,732 \\
\hline Euglossa cognata Moure, 1970 & 03 & 01 & 06 & 09 & 09 & 28 \\
\hline Euglossa clausi Nemésio \& Engel, 2012 & 65 & 01 & 01 & 00 & 03 & 70 \\
\hline Euglossa despecta Moure, 1968 & 19 & 06 & 13 & 09 & 06 & 53 \\
\hline Euglossa ignita Smith, 1874 & 10 & 11 & 52 & 09 & 23 & 105 \\
\hline Euglossa imperialis Cockerell, 1922 & 30 & 16 & 63 & 42 & 17 & 168 \\
\hline Euglossa liopoda Dressler, 1982 & 00 & 00 & 01 & 00 & 00 & 01 \\
\hline Euglossa marianae Nemésio, 2011b & 56 & 43 & 16 & 40 & 59 & 214 \\
\hline Euglossa milenae Bembé, 2007 & 00 & 02 & 00 & 00 & 00 & 02 \\
\hline Euglossa mixta Friese, 1899 & 66 & 10 & 02 & 04 & 52 & 134 \\
\hline Euglossa monnei Nemésio, 2012 & 02 & 00 & 01 & 02 & 02 & 07 \\
\hline Euglossa pleosticta Dressler, 1982 & 19 & 02 & 11 & 02 & 02 & 36 \\
\hline Euglossa roubiki Nemésio, 2009 & 65 & 16 & 51 & 10 & 14 & 156 \\
\hline Euglossa securigera Dressler, 1982 & 19 & 01 & 06 & 01 & 07 & 34 \\
\hline Eulaema atleticana Nemésio, 2009 & 00 & 03 & 01 & 01 & 01 & 06 \\
\hline Eulaema marcii Nemésio, 2009 & 12 & 01 & 17 & 04 & 41 & 75 \\
\hline Eulaema nigrita Lepeletier, 1841 & 41 & 42 & 55 & 41 & 48 & 227 \\
\hline Eulaema niveofasciata (Friese, 1899) & 07 & 02 & 03 & 00 & 07 & 19 \\
\hline Exaerete frontalis (Guérin-Méneville, 1844) & 01 & 00 & 00 & 02 & 01 & 04 \\
\hline Exaerete smaragdina (Guérin-Méneville, 1844) & 05 & 09 & 12 & 04 & 05 & 35 \\
\hline Total & 615 & 348 & 1,089 & 589 & 584 & 3,225 \\
\hline Species richness $(\mathrm{S})$ & 20 & 19 & 20 & 18 & 22 & 24 \\
\hline Shannon-Wiener diversity index (H') & 2.36 & 1.88 & 1.33 & 1.37 & 2.15 & 1.89 \\
\hline Evenness $(\mathrm{E})$ & 0.79 & 0.64 & 0.44 & 0.47 & 0.69 & 0.59 \\
\hline
\end{tabular}


sites according to their faunas (Figure 2) showed a great overall similarity among the sites, particularly those at RNV. Sites RNV-2 and RNV-3, the two closest to the coast, grouped together with ca. $88 \%$ similarity, and sites RNV-1 and RNV-4, situated in the best preserved forest patches at RNV, grouped together with ca. $80 \%$ similarity (Figure 2). 'REBIO Sooretama' grouped with all sites at RNV with ca. $65 \%$ similarity (Figure 2), but showed a higher similarity (over $70 \%$ with sites RNV-1 and RNV-4).

In comparison to the previous study by Bonilla-Gómez (1999), it was revealed in this study that the abundance of orchid bee males (32.6 bees/hour, considering only RNV sites) was extremely similar to those previously found (30 bees/hour) at the same sites twelve years before - it raises to 38.9 bees/hour if only samplings in April and December are considered (Bonilla-Gómez, 1999). Eight species were considered to have their habitat preferences well-defined, four of them typically associated to open or disturbed habitats (or edges of well-preserved forest patches), and four species were associated to the interior

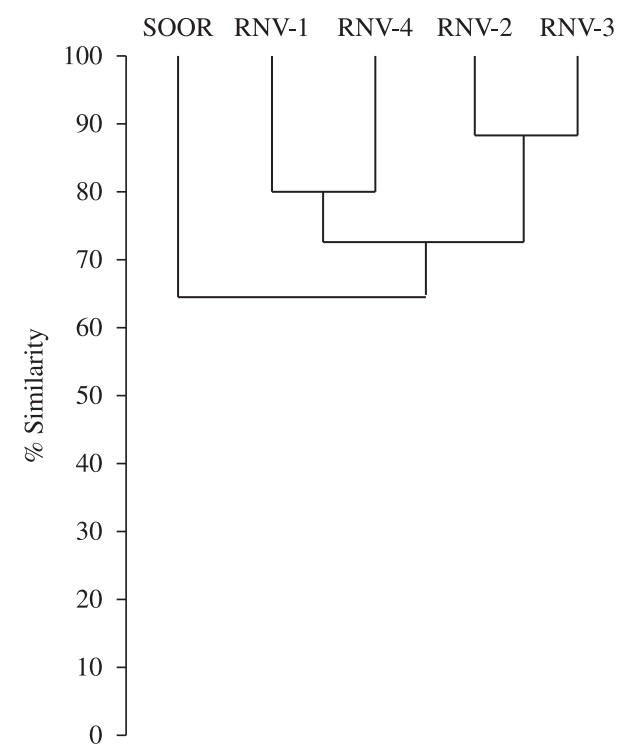

Figure 2. Clustering of the four sites at the 'Reserva Natural Vale' (RNV-1 to RNV-4) and the site at 'REBIO Sooretama' (Soor), according to the similarity (Renkonen) of their orchid bee faunas. of forests in well-preserved forest patches (see Table 2). All four species considered as forest dependent showed a clear tendency for a decline in their populations, both when considering their relative abundances (towards the overall orchid-bee community), and when considering their absolute abundance (number of specimens/sampling effort in hours). In contrast, three of the four species more tolerant to open or disturbed habitats showed a raise in their populations in both analyses (Tables 2 and 3). The only exception was Eulaema nigrita Lepeletier, 1841, which was considered to be a species tolerant to open habitats but which population declined (Tables 2 and 3). These abundance changes over time, however, were not statistically significant for most species (see Table 3). Nevertheless, abundance changes of Euglossa marianae, the most forest-dependent of all orchid bees in the Atlantic Forest, showed a significant value $(\mathrm{P}=0.022)$; an almost significant value $(\mathrm{P}=0.054)$ was found for Euglossa cognata, a close ally of $E$. marianae and also strongly associated to large, well-preserved forest patches.

\section{Discussion}

The efficiency of the methodology employed here, already used before with remarkable results (Nemésio 2010b; 2011a, b; Nemésio et al., 2012), revealed that this strategy can equal the collection rates of traditional inventories with monthly samplings. Nevertheless, as most collections made in RNV (sites 1 to 3 ) occurred at the end of the wet season, when species of the highly seasonal genus Eufriesea were not active, the relative abundance of species of this genus is certainly underestimated. BonillaGómez (1999) recorded five species of Eufriesea at RNV, whereas only two species were recorded in the present study. Bonilla-Gómez (1999) recorded twenty species of Euglossa, four of Eulaema (all recorded in the present study) and two of Exaerete (both recorded in the present study), totalling 31 orchid-bee species. Four species of Euglossa recorded by Bonilla-Gómez (1999) were not collected in the present study, but they may represent misidentifications, as discussed by Nemésio (2009). Furthermore, these additional species were represented by few (three or less) specimens. The bee treated as Euglossa magnipes Dressler, 1982 by Bonilla-Gómez (1999) is probably Eg. monnei Nemésio, 2012. Differences in nomenclature between Bonilla-Gómez (1999) and the

Table 2. Comparing relative abundance (to overall community) of species tolerant to open habitats and species dependent on environments in the interior of forests from two studies carried out at 'Reserva Natural Vale', in the state of Espírito Santo, eastern Brazil, with a time span of 12 years between both samplings.

\begin{tabular}{lccc}
\hline \multicolumn{1}{c}{ Species } & Habitat preference & Bonilla-Gómez (1999) (\%) & Present study (\%) \\
\hline Euglossa carolina & Open & 44.2 & 59.6 \\
Euglossa ignita & Open & 3.1 & 3.6 \\
Euglossa mixta & Open & 0.7 & 2.6 \\
Eulaema nigrita & Open & 10.2 & 7.1 \\
Euglossa cognata & Forest & 2.3 & 1.0 \\
Euglossa imperialis & Forest & 7.1 & 5.3 \\
Euglossa marianae & Forest & 16.9 & 6.1 \\
Euglossa roubiki & Forest & 6.2 & 3.5 \\
\hline
\end{tabular}


Table 3. Comparing the absolute abundance of species tolerant to open habitats and species dependent on environments in the interior of forests from two studies carried out at 'Reserva Natural Vale', in the state of Espírito Santo, eastern Brazil, with a time span of 12 years between both samplings. Values represent the mean number $( \pm$ S.E.) of bees captured per hour in each sampling site ( $\mathrm{n}=9$ and $\mathrm{n}=4$, respectively, for the Bonilla-Gómez's and the present study). P-values are from $t$-tests (data were square-root transformed prior to the analyses).

\begin{tabular}{lcccc}
\hline \multicolumn{1}{c}{ Species } & Habitat & Bonilla-Gómez (1999) & Present study & P-value \\
\hline Euglossa carolina & Open & $13.2 \pm 2.6$ & $19.4 \pm 6.6$ & 0.803 \\
Euglossa ignita & Open & $0.9 \pm 0.2$ & $1.2 \pm 0.5$ & 0.623 \\
Euglossa mixta & Open & $0.2 \pm 0.05$ & $0.9 \pm 0.6$ & 0.110 \\
Eulaema nigrita & Open & $3.1 \pm 1.1$ & $2.3 \pm 0.2$ & 0.232 \\
Euglossa cognata & Forest & $0.7 \pm 0.1$ & $0.3 \pm 0.1$ & 0.054 \\
Euglossa marianae & Forest & $5.1 \pm 0.7$ & $2.0 \pm 0.4$ & 0.022 \\
Euglossa imperialis & Forest & $2.1 \pm 0.3$ & $1.7 \pm 0.6$ & 0.425 \\
Euglossa roubiki & Forest & $1.8 \pm 0.3$ & $1.1 \pm 0.5$ & 0.182 \\
\hline
\end{tabular}

present study were already discussed by Nemésio (2009, 2011a, b, 2012) and Nemésio and Rasmussen (2011), with the exception of the above mentioned Eg. monnei and the also recently described Eg. marianae (treated as Eg. analis in Bonilla-Gómez's study).

The dominance of Eg. carolina in all sampling sites is striking and deserves further consideration as this species has been associated to highly disturbed environments (discussed by Tonhasca Junior et al., 2002a; Nemésio and Silveira, 2006a; Nemésio, 2009, 2011a), and it is one of the most common orchid-bee species in urban areas in Espírito Santo and Bahia (pers. obs.). Since 'REBIO Sooretama' and RNV are the largest and best preserved patches of forest in the state of Espírito Santo, it would be expected to find a more diverse orchid-bee fauna, with a predominance of forest-dependent species. Nevertheless, the overall evenness found at RNV is very low, particularly at RNV-2 and RNV-3, the sites located closest to the coast and on sandy soils. The results found here are similar to those by Bonilla-Gómez (1999), when Eg. carolina - treated as Eg. cordata in that study - represented almost $45 \%$ of the total community. A possible explanation for this apparent contradiction is that all of the surrounding areas of both preserves are made up of pastures and crop plantations, which are suitable environments for Eg. carolina. Moreover, the extensive perimeter of RNV, with its obvious edge effects, make this preserve particularly suitable for species typical of open habitats, since there are few areas of environment deep inside the forest. It is not surprising, thus, that Eulaema nigrita, another species typical of open habitats (see Morato, 1998; Tonhasca Junior et al., 2002a; Nemésio and Silveira, 2006a), was the second most abundant species in the present study - and the third most abundant in Bonilla-Gómez's (1999) study. A lower abundance of Eg. carolina and, particularly, of El. nigrita (only the sixth most abundant) in the neighbouring 'REBIO Sooretama' (see Table 1), a much more compact (which reduces edge effects) forest patch (see Figure 1), seems to corroborate the hypothesis above. Finally, another apparent paradox is also supportive of the hypothesis above: Eg. marianae, considered as a species highly sensitive and dependent on environments typical of deep forest (see Tonhasca Junior et al., 2002a; Nemésio and
Silveira, 2006a; Nemésio, 2010b, 2011a - in all these works treated as Eg. analis - and Nemésio 2011b), was the third most common species in the region - the second one in Bonilla-Gómez's (1999) study, and its relative abundance was higher in 'REBIO Sooretama' and the best preserved sites at RNV (sites 1 and 4). This apparent contradiction (the most tolerant and sensitive orchid-bee species are the most common ones in the same area) may suggest that these areas are the only ones large enough to hold viable populations of Eg. marianae, but being surrounded by open habitats, may have been "invaded" by a species highly tolerant to disturbed areas. It is very important to notice that the present study was carried out twelve years after the end of Bonilla-Gómez's work field, in 1997. Euglossa marianae represented, then, $17 \%$ of the total community of orchid bees ( $21 \%$ if only samplings in April and December are considered) and only $6.6 \%$ of the total community in the present study (see Table 1). Even in the sites where this species was most abundant ('REBIO Sooretama' and RNV-4), it barely reached $10 \%$. If the data obtained in the present study is to be trusted, one must consider the possibility that this species declined roughly $50 \%$ of its contribution to the total community of orchid bees in 12 years, exactly what Nemésio (2011b) suggested to have happened in the smaller forest patches situated in the northern section of Espírito Santo, where this species seems to have declined to extinction in about 40 years. If both species compete for any kind of resources, it seems that Eg. carolina is a serious competitor and may put pressure on the survival of the Eg. marianae population at both preserves, particularly at RNV.

Tonhasca Junior et al. (2002a) were the first to notice that Eg. marianae populations could be "trapped" in the largest forest patches in the Atlantic Forest, with no migration (Tonhasca Junior et al. 2003). Nemésio and Silveira (2006a) showed that this species has a strong preference for the inner areas of large forest patches, but it was only recently that it was warned that this species may be facing a real risk of extinction, since it has not been found in forest preserves smaller than 6,000 ha (see Nemésio, 2011b). In fact, Nemésio (2011b) was only able to confirm its presence in 15 areas in the Atlantic Forest, and suggested that it may be locally extinct in two of them, 
since old records of this species could not be recently confirmed in two areas of northern Espírito Santo. Although populations of most insects, orchid bees included, tend to fluctuate over time (Roubik, 2001), it seems unreasonable to consider the situation of the Eg. marianae population as a simple matter of fluctuation over time. A more detailed comparison between Bonilla-Gómez's (1999) and the present study, focusing on species typically tolerant to open or disturbed habitats and on species typically dependent on environments in the interior of forests shows that all species typical of deep forest interiors declined their abundances, whereas most of those typical of open or disturbed habitats increased their abundances (see Tables 2 and 3). Thus, it doesn't seem to have been a phenomenon affecting only a particular species, but a series of species more sensitive to deforestation and consequent loss of suitable habitats. It is important to stress, however, that the decline reported here was observed in a short 12-year time span. It may take some more time to be definitely noticed for other species, theoretically less sensitive than Eg. marianae.

More studies are obviously necessary to further investigate the hypothesis presented here. Only two studies, however, were carried out in large forest remnants (> 20,000 ha) more than ten years ago in the Atlantic Forest: that by Tonhasca Junior et al. (2002a), when samplings were carried out from 1997 to 1999 , and the one by Nemésio and Silveira (2006a), when samplings took place from 1999 to 2000. Repetition of surveys in these areas, preferably at the same sampling sites, would allow a better understanding of the effects of habitat fragmentation on populations of highly sensitive orchid-bee species.

Acknowledgements - The Brazilian government, through the environmental departments IBAMA and ICMBio, provided the collecting permit (\#18131-8). I express my gratitude to Renato de Jesus, Ana Carolina Srbek de Araújo and José Simplício dos Santos, who allowed the present research and provided all facilities for my studies at Reserva Natural Vale, and Eliton Lima and Valdir Santos, who authorized and were very helpful during my field research at Reserva Biológica Sooretama. I also thank Heraldo L. Vasconcelos for helping with statistical analyses and also for reading and commenting on previous versions of this manuscript. I am also indebted to the valuable comments provided by one anonymous referee.

\section{References}

AGUIAR, WM. and GAGLIANONE, MC., 2008. Comunidade de abelhas Euglossina (Hymenoptera: Apidae) em remanescentes de mata estacional semidecidual sobre tabuleiro no estado do Rio de Janeiro. Neotropical Entomology, vol. 37, p. 118-125. PMid:18506288. http://dx.doi.org/10.1590/S1519-566X2008000200002

-, 2011. Euglossine bees (Hymenoptera Apidae Euglossina) on an inselberg in the Atlantic Forest domain of southeastern Brazil. Tropical Zoology, vol. 24, p. 107-125.

ALVARENGA, PEF., FREITAS, RF. and AUGUSTO, SC., 2007. Diversidade de Euglossini (Hymenoptera: Apidae) em áreas de Cerrado do Triângulo Mineiro, MG. Bioscience Journal, vol. 23, supplement 1, p. 30-37.

BONILLA-GÓMEZ, MA., 1999. Caracterização da Estrutura Espaço-temporal da Comunidade de Abelhas Euglossinas (Hymenoptera, Apidae) na Hiléia Bahiana. Campinas: Universidade Estadual de Campinas. 153 p. Unpublished Ph. D. Dissertation.
FRIESE, H., 1899. Monographie der Bienengattung Euglossa Latr. Természetrajzi Füzetek, vol. 22, p. 117-172.

Fundação SOS Mata Atlântica, 1993. Dossiê Mata Atlântica. São Paulo: Fundação SOS Mata Atlântica.

GIANGARELLI, DC., FREIRIA, GA., COLATRELI, OP., SUZUKI, KM. and SOFIA, SH., 2009. Eufriesea violacea (Blanchard) (Hymenoptera: Apidae): na orchid bee apparently sensitive to size reduction in forest patches. Neotropical Entomology, vol. 38, p. 610-615. Pmid:19943008. http://dx.doi.org/10.1590/ S1519-566X2009000500008

HINOJOSA-DÍAZ, IA., NEMÉSIO, A. and ENGEL, MS., 2012. Two new species of Eugossa from South America, with notes on their taxonomic affinities (Hymenoptera, Apidae). ZooKeys, vol. 221, p. 63-79. http://dx.doi.org/10.3897/zookeys.221.3659

Instituto Brasileiro de Geografia e Estatística - IBGE, 1993. Mapa de Vegetação do Brasil. Rio de Janeiro: IBGE.

International Union for Conservation of Nature - IUCN, 2001. The IUCN Red List of Threatened Species. Categories and Criteria. version 3.1. Available from: <http://www.iucnredlist.org/info/ categories_criteria2001\#critical>. [Access in: 20 Jan. 2012.

MARTINS, CF. and SOUZA, AKP., 2005. Estratificação vertical de abelhas Euglossina (Hymenoptera, Apidae) em uma área de Mata Atlântica, Paraíba, Brasil. Revista Brasileira de Zoologia, vol. 22, p. 913-918. http://dx.doi.org/10.1590/S0101-81752005000400016

MOCSÁRY, A., 1896. Species Hymenopterorum magnificæ novæ in collectione musæi nationalis Hungarici. Természetrajzi Füzetek, vol. 19, p. 1-8.

-, 1897. Species septem novæ generis Euglossa Latr. in collectione musaei nationalis Hungarici. Természetrajzi Füzetek, vol. 20, p. $442-446$

MORATO, EF., 1994. Abundância e riqueza de machos de Euglossini (Hymenoptera: Apidae) em mata de terra firme e áreas de der-rubada, nas vizinhanças de Manaus (Brasil). Boletim do Museu Paraense Emílio Goeldi, Série Zoologia, vol. 10, p. 95-105.

-, 1998. Estudos sobre comunidades de abelhas Euglossini. Anais do Encontro sobre Abelhas, vol. 3, p. 135-143.

MORATO, EF., CAMPOS, LAO. and MOURE, JS., 1992. Abelhas Euglossini (Hymenoptera, Apidae) coletadas na Amazônia Central. Revista Brasileira de Entomologia, vol. 36, p. 767-771.

NEMÉSIO, A., 2003. Preliminary sampling of Euglossina (Hymenoptera: Apidae: Apini) of Reserva Particular do Patrimônio Natural Feliciano Miguel Abdala, Caratinga, Minas Gerais state, Brazil. Lundiana, vol. 4, p. 121-124.

-, 2008a. Eufriesea atlantica (Hymenoptera: Apidae), a new orchid bee from the Brazilian Atlantic Forest. Lundiana, vol. 8, p. $147-152$.

-, 2008b. Orchid bee community (Hymenoptera, Apidae) at an altitudinal gradient in a large forest fragment in southeast-ern Brazil. Revista Brasileira de Zoociências, vol. 10, p. 251-258.

-, 2009. Orchid bees (Hymenoptera: Apidae) of the Brazilian Atlantic Forest. Zootaxa, vol. 2041, p. 1-242.

-, 2010a. Eulaema (Apeulaema) felipei sp. n. (Hymenoptera: Apidae: Euglossina): a new forest-dependent orchid bee found at the brink of extinction in northeastern Brazil. Zootaxa, vol. 2424, p. 51-62.

-, 2010b. The orchid-bee fauna (Hymenoptera: Apidae) of a forest remnant in northeastern Brazil, with new geographic records and an identification key to the known species of the Atlantic Forest of northeastern Brazil. Zootaxa, vol. 2656, p. 55-66.

-, 2011a. The orchid-bee fauna (Hymenoptera: Apidae) of a forest remnant in southern Bahia, Brazil, with new geographic 
records and an identification key to the known species of the area. Zootaxa, vol. 2821, p. 47-54.

-, 2011b. Euglossa marianae sp. n. (Hymenoptera: Apidae): a new orchid bee from the Brazilian Atlantic Forest and the possible first documented local extinction of a forest dependent orchid bee. Zootaxa, vol. 2892, p. 59-68.

-, 2011c. Exaerete salsai sp. n. (Hymenoptera: Apidae): a new orchid bee from eastern Brazil. Zootaxa, vol. 2967, p. 12-20.

-, 2011d. Euglossa bembei sp. n. (Hymenoptera: Apidae): a new orchid bee from the Brazilian Atlantic Forest belonging to the Euglossa cybelia Moure, 1968 species group. Zootaxa, vol. 3006, p. 43-49.

-, 2011e. Rediscovered after forty-two years: the rare orchid bee Eufriesea brasilianorum (Hymenoptera: Apidae) of eastern Brazil. North-Western Journal of Zoology, vol. 7, p. 356-359.

-, 2012. Species of Euglossa Latreille, 1802 (Hymenoptera: Apidae: Euglossina) belonging to the purpurea species group occurring in eastern Brazil, with description of Euglossa monnei sp. n. Zootaxa, vol. 3151, p. 35-52.

NEMÉSIO, A., CERÂNTOLA, NCM., VASCONCELOS, HL., NABOUT, JC., SILVEIRA, FA. and DEL LAMA, MA., 2012. Searching for Euglossa cyanochlora Moure, 1996 (Hymenoptera: Apidae), one of the rarest bees in the world. Journal of Insect Conservation, vol. 16, p. 745-755. http://dx.doi.org/10.1007/ s10841-012-9459-2.

NEMÉSIO, A. and ENGEL, MS., 2012. Three new cryptic species of Eugossa from Brazil (Hymenoptera, Apidae). ZooKeys, vol. 222, p. 47-68. http://dx.doi.org/10.3897/zookeys.222.3382

NEMÉSIO, A. and FARIA JUNIOR, LRR., 2004. First assessment of orchid bee fauna (Hymenoptera: Apidae: Apini: Euglossina) of Parque Estadual do Rio Preto, a cerrado area in southeastern Brazil. Lundiana, vol. 5, p. 113-117.

NEMÉSIO, A. and RASMUSSEN, C., 2011. Taxonomic issues in the orchid bees (Hymenoptera: Apidae: Euglossina), and an updated catalogue. Zootaxa, vol. 3006, p. 1-42.

NEMÉSIO, A. and SILVEIRA, FA., 2004. Biogeographic notes on rare species of Euglossina (Hymenoptera: Apidae: Apini) occurring in the Brazilian Atlantic Rain Forest. Neotropical Entomology, vol. 33, p. 117-120. http://dx.doi.org/10.1590/ S1519-566X2004000100021

-, 2006a. Edge effects on the orchid-bee fauna (Hymenoptera: Apidae) at a large remnant of Atlantic Forest in southeastern Brazil. Neotropical Entomology, vol. 35, p. 313-323. PMid:18575690. http://dx.doi.org/10.1590/S1519-566X2006000300004

-, 2006b. First record of Eulaema helvola (Hymenoptera: Apidae: Euglossina) for the state of Minas Gerais: biogeographic and taxonomic implications. Neotropical Entomology, vol. 35, p. 418-420. PMid:18575707. http://dx.doi.org/10.1590/S1519566X2006000300021

-, 2007. Orchid bee fauna (Hymenoptera: Apidae: Euglossina) of Atlantic Forest fragments inside an urban area in southeastern Brazil. Neotropical Entomology, vol. 36, p. 186-191. PMid:17607450. http://dx.doi.org/10.1590/S1519-566X2007000200003

-, 2010. Forest fragments with larger core areas better sustain diverse orchid bee faunas (Hymenoptera: Apidae: Euglossina). Neotropical Entomology, vol. 39, p. 555-561. PMid:20877991. http://dx.doi.org/10.1590/S1519-566X2010000400014

NEVES, EL. and VIANA, BF., 1997. Inventário da fauna de Euglossinae (Hymenoptera: Apidae) do baixo sul da Bahia, Brasil. Revista Brasileira de Zoologia, vol. 4, p. 831-837.
-, 1999. Comunidade de machos de Euglossinae (Hymenoptera: Apidae) das matas ciliares da margem esquerda do médio rio São Francisco, Bahia. Anais da Sociedade Entomológica do Brasil, vol. 28, p. 201-210. http://dx.doi.org/10.1590/S030180591999000200002

-, 2003. A fauna de abelhas da subtribo Euglossina (Hymenoptera: Apidae) do estado da Bahia, Brasil. In MELO, GAR. \& ALVESDOS-SANTOS, I. (Eds.). Apoidea Neotropica: Homenagem aos 90 anos de Jesus Santiago Moure. Criciúma: Universidade do Extremo Sul Catarinense. p. 223-229.

OLIVEIRA-FILHO, AT. and FONTES, MAL., 2000. Patterns of floristic differentiation among Atlantic forests in southeastern Brazil and the influence of climate. Biotropica, vol. 32, p. 793-810.

PERUQUETTI, RC., CAMPOS, LAO., COELHO, CDP., ABRANTES, CVM. and LISBOA, LCO., 1999. Abelhas Euglossini (Apidae) de áreas de Mata Atlântica: abundância, riqueza e aspectos biológicos. Revista Brasileira de Zoologia, vol. 16, suplemento 2, p. 101-118

PIELOU, EC., 1975. Ecological diversity. New York: John Wiley \& Sons. 165 p.

POWELL, AH. and POWELL, GVN., 1987. Population dynamics of male euglossine bees in Amazonian forest fragments. Biotropica, vol. 19, p. 176-179. http://dx.doi.org/10.2307/2388742

RAMALHO, AV., GAGLIANONE, MC. and OLIVEIRA, ML., 2009. Comunidades de abelhas Euglossina (Hymenoptera, Apidae) em fragmentos de Mata Atlântica no sudeste do Brasil. Revista Brasileira de Entomologia, vol. 53, p. 95-101. http:// dx.doi.org/10.1590/S0085-56262009000100022

RAW, A., 1989. The dispersal of euglossine bees between isolated patches of eastern Brazilian wet Forest. Revista Brasileira de Entomologia, vol. 33, p. 103-107.

RIBEIRO, MC., METZGER, JP., MARTENSEN, AC., PONZONI, FJ. and HIROTA, MM., 2009. The Brazilian Atlantic Forest: how much is left, and how is the remaining forest distributed? Implications for conservation. Biological Conservation, vol. 142, p. 114-1153.

ROUBIK, DW., 2001. Ups and downs in pollinator populations: when is there a decline? Conservation Ecology, vol. 5. Available from: <url: http://www.consecol.org/vol5/iss1/art2>.

SNEATH, PHA. and SOKAL, RR., 1973. Numerical taxonomy. The principles and practice of numerical classification. San Francisco: W. H. Freeman. 573 p.

SRBEK-ARAÚJO, AC., SCOSS, LM., HIRSCH, A. and CHIARELLO, AG., 2009. Records of the giant-armadillo Priodontes maximus (Cingulata: Dasypodidae) in the Atlantic Forest: are Minas Gerais and Espírito Santo the last strongholds of the species? Zoologia, vol. 26, p. 461-468.

TONHASCA JUNIOR, A., BLACKMER, JL. and ALBUQUERQUE, GS., 2002a. Abundance and diversity of euglossine bees in the fragmented landscape of the Brazilian Atlantic Forest. Biotropica, vol. 34 , p. 416-422.

-, 2002b. Within-habitat heterogeneity of euglossine bee populations: a re-evaluation of the evidence. Journal of Tropical Ecology, vol. 18 , p. 929-933.

TONHASCA JUNIOR, A., ALBUQUERQUE, GS. and BLACKMER, JL., 2003. Dispersal of euglossine bees between fragments of the Brazilian Atlantic Forest. Journal of Tropical Ecology, vol. 19, p. 99-102.

WOLDA, H., 1981. Similarity indices, sample sizes and diversity. Oecologia, vol. 50, p. 296-302. http://dx.doi.org/10.1007/ BF00344966 